\title{
CORROSION OF MODULAR HIP PROSTHESES
}

\author{
ERIK B. MATHIESEN， J. URBAN LINDGREN， GUDMUND G. A. BLOMGREN， FINN P. REINHOLT
}

\author{
From the Karolinska Institute, Sweden
}

\begin{abstract}
Nine uncemented hip prostheses of modular design were revised because of late infection ( 2 cases), femoral stem loosening or fracture (2), loosening of threaded cups (3) and protrusion of bipolar cups (2). At surgery we found tissue discoloration and macroscopic corrosion in four of the nine prostheses, located at the head-neck junction. Histological examination in most cases showed extensive necrosis associated with metal particles, indicating metal toxicity.

Metallographic examination of the prosthetic heads revealed structural imperfections and inhomogeneity of the metal. We suggest that the crevice between the head and neck is a potential site of corrosion in modular designs.
\end{abstract}

Cobalt-chromium alloys have been successfully used as orthopaedic implant materials for more than half a century. Cast cobalt-chromium, still used for porouscoated devices, is mechanically inferior to wrought, forged or powder metallurgy processed alloys. The corrosion properties of the different types of cobalt-based alloys are, however, essentially similar. In this respect they are generally regarded as superior to stainless steels (Syrett and Davis 1979; Williams 1982; Kumar et al 1985).

At present there is a trend towards modular design of hip implants. Multicomponent systems reduce the necessary inventory and therefore the cost of arthroplasty and their versatility is an advantage.

In some revision operations we found extensive local tissue reaction associated with corroded implants. We have analysed the retrieved components and the adjacent tissues.

\section{MATERIALS AND METHODS}

From December 1979 to December 1983, 114 uncemented Lord madreporic hip prostheses (Benoist Girard, Bagneux, France) were implanted at Huddinge University Hospital. The prostheses are made of cast cobaltchromium (Francobal), which is an ASTM type F75 alloy.

E. B. Mathiesen, MD, Orthopaedic Surgeon

J. U. Lindgren, MD, PhD, Professor of Orthopaedic Surgery

G. G. A. Blomgren, MD, PhD, Orthopaedic Surgeon

F. P. Reinholt, MD, PhD, Senior Lecturer in Pathology

Departments of Orthopaedic Surgery and Pathology, Karolinska Institute, Huddinge University Hospital, 14186 Huddinge, Sweden.

Correspondence should be sent to Dr E. B. Mathiesen.

(C) 1991 British Editorial Society of Bone and Joint Surgery $0301-620 X / 91 / 4156 \$ 2.00$

J Bone Joint Surg [Br] 1991; 73-B: 569-75.
About half the femoral components, those implanted before 1982, were of modular design. After that date components with welded heads were used. By September 1988, 12 hips in 12 patients had been revised; all but one were of the modular design. Three of these revisions were performed less than one year postoperatively due to mechanical problems, and were not included. The study was therefore based on nine hips, revised after a mean of 52 months (range 16 to 72). Sex and age distribution, preoperative diagnosis, type of prosthesis, time in situ, reason for revision, and type of revision are shown in Table I.

Radiology. Plain radiographs were taken pre-operatively. Technetium scans $\left({ }^{99 \mathrm{~m}} \mathrm{Tc}-\mathrm{HDP}\right.$ or ${ }^{99 \mathrm{~m} T c-D P D)}$ were done in all cases except for the patient who had a broken femoral stem.

Bacteriology. Joint aspirates were cultured under aerobic and anaerobic conditions in seven patients (cases 1, 3, 4, 5, 6, 7 and 9). At surgery multiple tissue samples were obtained from all patients, for aerobic and anaerobic cultures, before prophylactic antibiotics were given.

Table I. Details of nine patients, reoperated for infection or aseptic loosening of uncemented Lord prostheses

\begin{tabular}{llllll}
\hline Case & $\begin{array}{l}\text { Sex: } \\
\text { age }\end{array}$ & $\begin{array}{l}\text { Reason for } \\
\text { arthroplasty }\end{array}$ & $\begin{array}{l}\text { Cup } \\
\text { type }\end{array}$ & $\begin{array}{l}\text { In situ } \\
\text { (mth) }\end{array}$ & Reason for revision \\
\hline 1 & M:70 & Fracture & Bipolar & 16 & Stem loosening \\
2 & M:71 & Fracture & Cemented & 39 & Stem fracture \\
3 & F $: 59$ & OA & Threaded & 42 & Inflammatory reaction \\
4 & M:62 & OA & Threaded & 59 & Cup loosening \\
5 & F:56 & OA & Bipolar & 59 & Cup protrusion \\
6 & F:50 & Fracture & Bipolar & 55 & Cup protrusion \\
7 & M:54 & Fracture & Threaded & 72 & Cup loosening \\
8 & F:55 & Fracture & Bipolar & 65 & Infection \\
9 & M:55 & Fracture & Bipolar & 64 & Infection \\
\hline
\end{tabular}


Histological examination. Specimens for histological examination were fixed in $10 \%$ neutral buffered formalin, embedded in paraffin, cut at $6 \mu \mathrm{m}$, and stained with haematoxylin-eosin. Coded sections were examined by conventional and polarised light microscopy for semiquantitative classification. Necrosis, fibrosis, foreign-body reaction, inflammation and the presence of birefringent polyethylene wear debris, were classified on a 3-grade scale as described previously (Mathiesen et al 1987).

Scanning electron microscopy with energy dispersive analysis was performed in two cases in order to verify the presence of metal particles in the soft tissues.

Metallurgical analysis of retrieved prostheses. Nine modular heads were investigated metallurgically using light optical microscopy, scanning electron microscopy, and a microprobe. For comparison we also investigated a new $32 \mathrm{~mm}$ Lord modular head, and a retrieved modular head from another type of cobalt-chromium prosthesis (PCA, Howmedica Inc, New York).

In order to study the surface of the channel within the head in detail, each one was cut in half. One half was left untreated for light optical microscopy and for scanning electron microscopy. The other half was embedded in plastic, ground and polished. Subsequently it was etched with a solution of hydrogen dioxide and hydrochloric acid and examined by using light optical microscopy. The composition and distribution of alloying elements was determined by microprobe analysis.

\section{RESULTS}

Radiological findings. Various signs of bone remodelling, predominantly atrophy of the proximal femur, were found in all patients. Cases with protrusion of bipolar or threaded cups had acetabular bone resorption. One patient (case 3) with a loose threaded cup and osteopenia had a pathological fracture of the pubic bone.

The two infected cases showed cortical osteopenia and irregular bone resorption around the implants. One patient (case 9), had a radiopaque shadow at the junction between the head and the neck (Fig. 1). The cause of this was later shown to be corrosion products.

Pre-operative bone scans. Technetium scans revealed increased tracer activity around the implants of all patients examined. Those with acetabular loosening or protrusion of bipolar heads showed increased activity at the acetabulum, whereas the infected cases and those with stem loosening had increased activity all around the implant. In case 3, a large 'cold zone' at the centre of the joint was surrounded by a peripheral zone of increased activity.

Bacteriology. Pre-operative aspiration of joint fluid demonstrated no bacterial growth in six out of seven patients and Staphylococcus epidermidis in one (case 9). These findings were confirmed by bacterial cultures taken at surgery.

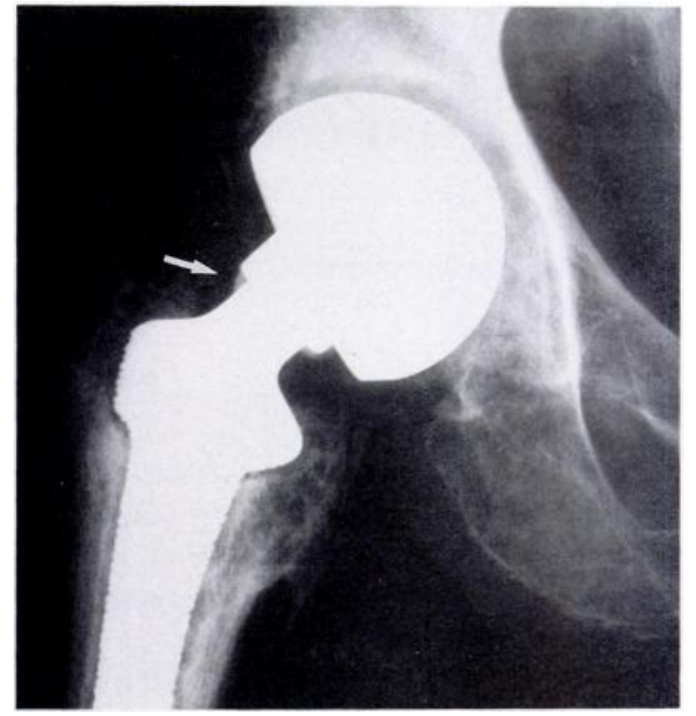

Fig. 1

An infected bipolar Lord prosthesis showing irregular bone resorption at the metal-bone interfaces (case 9). The radiopaque shadow at the angle between the head and neck (arrow) represents a deposit of corrosion products.

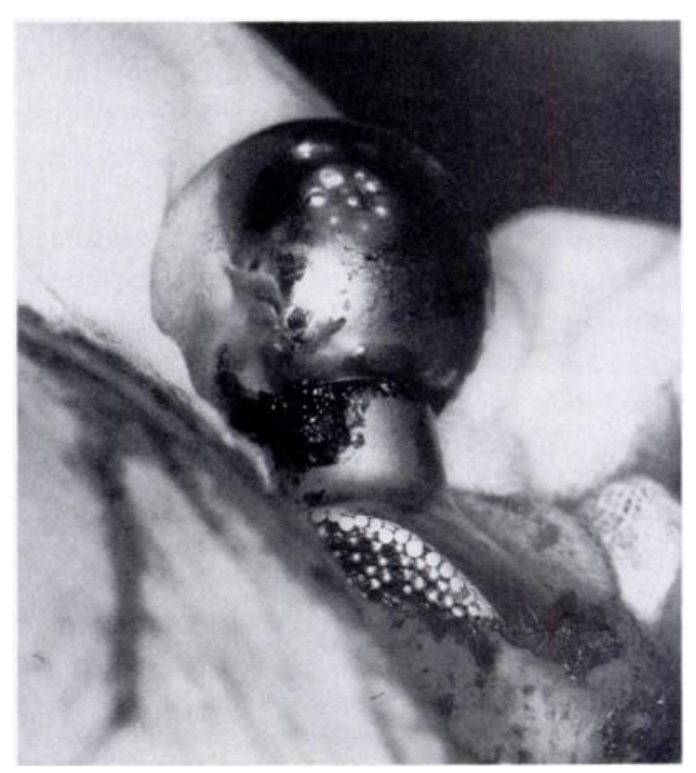

Fig. 2

Black deposits at the junction between the modular head and neck of a Lord prosthesis (case 3).

In case 8, from whom no pre-operative cultures were taken, Staphylococcus epidermidis, Staphylococcus aureus and Propionebacterium acnes were found in cultures obtained at the revision operation. Peri-operative cultures from the remaining seven patients were negative.

Appearances at operation. Four hips showed discoloration of bone and soft tissues (cases 3, 4, 7 and 9) and also had black deposits at the junction between the head and neck 
Figure 3a-The interior channel of a modular Lord head (case 9). The head has been cut in half to show the rough appearance of the surface. Figure $3 b-$ The interior channel of $a$ modular PCA head, extracted after 37 months for malpositioning. The channel surface is smooth and shiny.

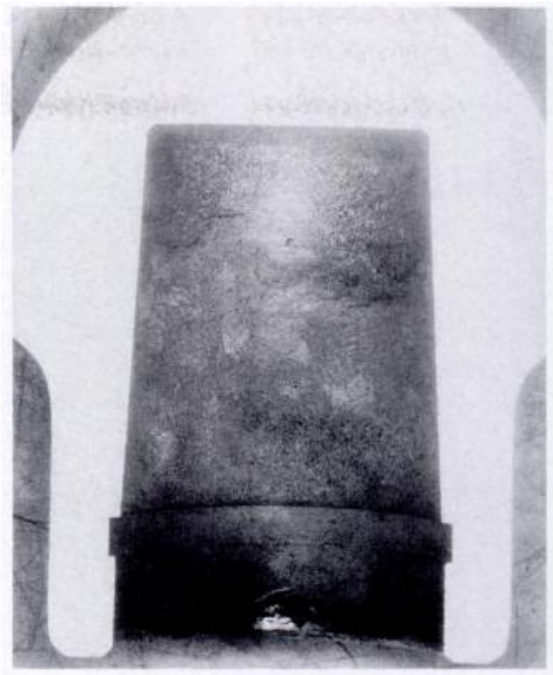

Fig. 3a



Fig. 3b

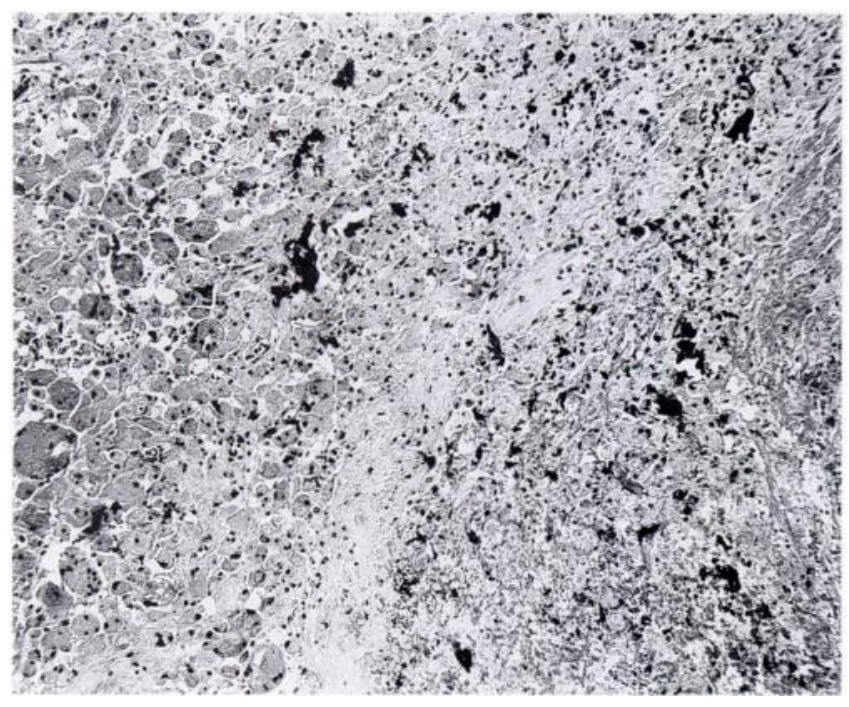

Fig. 4

Histology of soft tissues around a corroded prosthesis. Histiocytic proliferation and deposits of metal debris in the vicinity of a necrotic area (haematoxylin and eosin $\times 80$ ). of the prostheses (Fig. 2). The interior channel and the corresponding taper of the femoral neck was similarly discoloured and had a rough appearance in each of the four cases (Fig. 3a). The other five prostheses were macroscopically unaffected (Fig. 3b).

In the three threaded cups which were loose the acetabular cavity was lined with dark necrotic tissue. The polyethylene inlays of the threaded sockets in two patients (cases 4 and 7), were macroscopically worn. The other cups showed no sign of excessive wear.

The femoral stems of cases 4,5 and 6 were soundly fixed and were left in situ. The loose femoral stem in case 1 could easily be removed, whereas the extraction of the other five femoral stems, including the two infected cases, was extremely difficult.

Histology. The results of the histological examination are summarised in Table II. Metal particles were found in the soft tissues of six patients, including those with corroded prostheses (Fig. 4). Around the corroded prostheses there was extensive necrosis and various

Table II. Semiquantitative evaluation of the histological findings in nine uncemented Lord prostheses, reoperated for aseptic infection or aseptic loosening $0=$ none, $1+=$ small $/$ moderate, $2+=$ extensive $/$ large

\begin{tabular}{|c|c|c|c|c|c|c|}
\hline Case & Necrosis & Fibrosis & $\begin{array}{l}\text { Foreign-body } \\
\text { reaction }\end{array}$ & Inflammation & $\begin{array}{l}\text { Birefringent } \\
\text { material }\end{array}$ & Metal \\
\hline 1 & $1+$ & $1+$ & 0 & $1+$ & 0 & $1+$ \\
\hline 2 & $2+$ & $2+$ & $\mathbf{0}$ & 0 & 0 & 0 \\
\hline 3 & $2+$ & $2+$ & $1+$ & $2+$ & $1+$ & $1+$ \\
\hline 4 & $2+$ & 0 & $1+$ & $1+$ & $1+$ & $1+$ \\
\hline 5 & $2+$ & $1+$ & $2+$ & 0 & $2+$ & 0 \\
\hline 6 & 0 & $2+$ & $2+$ & 0 & $1+$ & 0 \\
\hline 7 & $2+$ & $1+$ & $1+$ & $1+$ & $1+$ & $1+$ \\
\hline 8 & $2+$ & $2+$ & 0 & $1+$ & $1+$ & $1+$ \\
\hline 9 & $2+$ & $1+$ & $1+$ & $2+$ & $1+$ & $2+$ \\
\hline
\end{tabular}




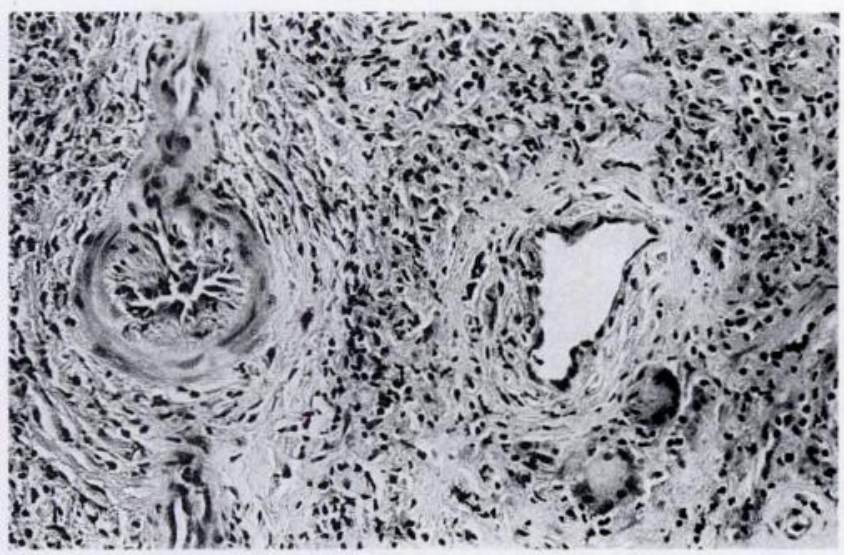

Fig. 5a



Fig. 5b

Histology of soft tissues around a corroded prosthesis. Figure 5a - Severe intimal swelling with slight lymphocytic inflammation in an artery (to

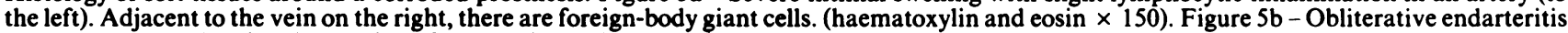
in a small artery, showing destruction of the media by giant cells (haematoxylin and eosin $\times 150$ ).

degrees of histiocytic proliferation with foreign-body giant cells. Infiltration of lymphocytes and plasma cells was common, even in the absence of infection. The findings in case 3 have been described in detail by Svensson et al (1988): there were extensive inflammatory changes with numerous eosinophils, and soft-tissue vessels exhibited signs of obliterative arteritis (Fig. 5). Case 9 showed similar, but less dramatic vascular changes with intimal swelling and outer degeneration of the media, but only limited perivascular infiltrates.

Scanning electron microscopy and energy dispersive analysis. Dark brown/black granules with birefringence were demonstrated with light microscopy in tissue samples from six patients. Samples from cases 3 and 4 showed peaks for cobalt, chromium, molybdenum, calcium and phosphorus (Fig. 6).

Metallographic examination. The microstructure of the prosthetic heads was similar for all Lord prostheses. The metal was cast, and characterised by large grain size, coarse dendrites, and interdendritic regions of carbides and shrinkage pores. In corroded heads, larger voids had been formed, giving an overall impression of porosity. In the modular head of the PCA prosthesis, studied for comparison, the grain size was smaller, and there were no signs of porosities.

Scanning electron microscopy of the untreated channel surface showed no evidence of corrosion in five modular heads, in which no discoloration was seen. By contrast, the surface appearance of discoloured channels displayed their cast structure. The appearances were like those seen in macro-etching, in which acid is used to reveal grain structure and physical defects (Fig. 7). The interdendritic phase had been etched by the body fluids, producing deep holes in the metal. Penetration to depths ranging from $400 \mu \mathrm{m}$ up to $4 \mathrm{~mm}$ could be demonstrated on cross sections (Fig. 8).

Microprobe analysis. The distribution of alloying elements of the corroded heads showed that the interden-

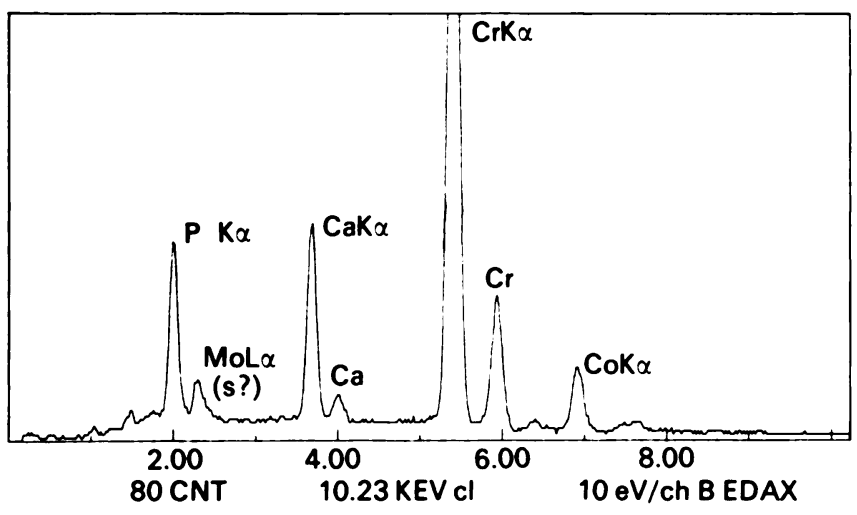

Fig. 6

Scanning electron microscopy of soft tissue from case 4 with energy dispersive analysis shows peaks for chromium, cobalt and molybdenum.

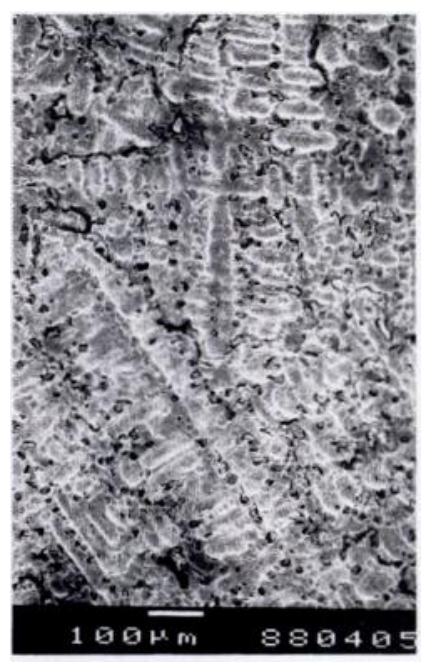

Fig. 7a

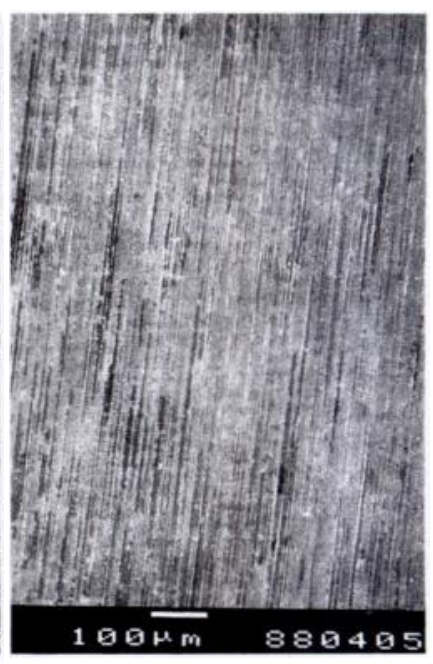

Fig. $7 b$
Figure 7a-Scanning electron microscopy of the channel surface of a Lord modular head (see Fig. 3a). The cast structure has been revealed by etching by the body fluids. The bar represents $100 \mu \mathrm{m}$. Figure $7 \mathrm{~b}-$ Scanning electron microscopy of the channel surface of a PCA modular head (see Fig. 3b). The bar represents $100 \mu \mathrm{m}$. 


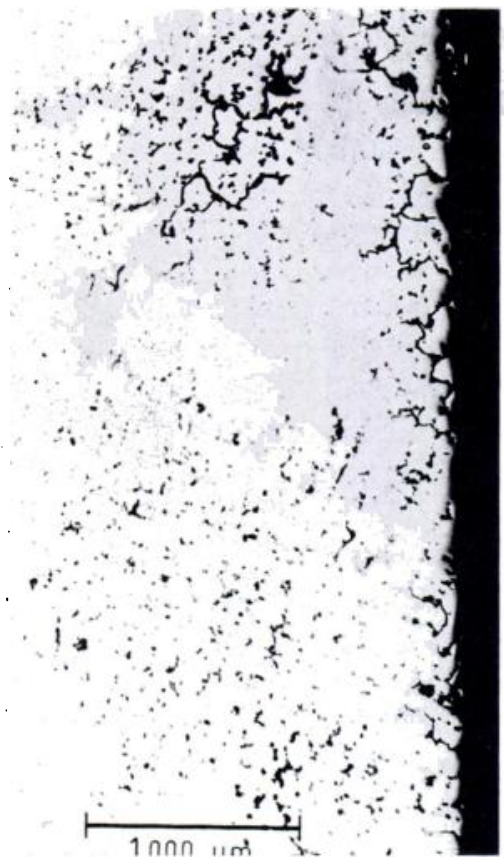

Fig. 8

Cross-section of a Lord modular head demonstrating porosities penetrating up to $2 \mathrm{~mm}$ from the channel surface on the right. The bar represents $1000 \mu \mathrm{m}$.

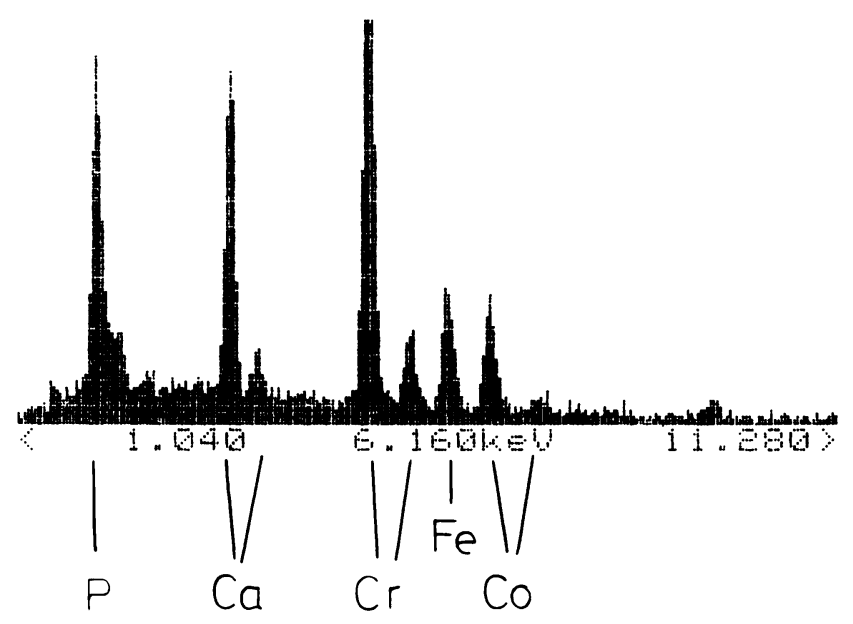

Fig. 9

Energy dispersive electron spectrometry analysis of black deposits at the head-neck junction of a corroded Lord prosthesis. The graph shows peaks for chromium, cobalt, iron, calcium and phosphorus.

dritic area, which is the last to solidify, contained a high level of molybdenum. Measurements of the elemental distribution close to the channel surface confirmed that it was the interdendritic phase, containing carbides, that had dissolved elsewhere at the surface. Because the metal had several phases, the microprobe could not be used to determine its exact composition. However, the results of an approximate analysis were within the limits of the manufacturer's specifications.
The exact chemical composition of the black deposits seen at the head-neck junction has not been analysed. However, cobalt, chromium, iron, phosphorus and calcium were detected using an energy-dispersive electron spectrometer in the microprobe (Fig. 9).

\section{DISCUSSION}

Local and systemic effects of cobalt-chromium. The toxic potential of cobalt-chromium has previously been demonstrated by several investigators (Mital and Cohen 1968; Pappas and Cohen 1968; Rae 1975, 1981; Evans and Thomas 1986). The histological findings in our material are essentially similar to those reported by Evans et al (1974), Jones et al (1975), and VernonRoberts and Freeman (1977). Necrosis and histiocytic proliferation were common findings. In our material, however, obliterative vascular changes were less frequent. Clusters of metal particles were often found in areas of extensive necrosis and mononuclear infiltration was more frequent.

Howie and Vernon-Roberts (1988) have described similar reactions, with the exception of vasculitis, to cobalt-chromium wear particles when injected into the knees of rats. Occasionally local eosinophilia has been found, suggesting a hypersensitivity reaction (Halpin 1975; Pizzoferrato et al 1988). Svensson et al (1988), reporting on case 3 in this paper, demonstrated the formation of an inflammatory pseudotumour with numerous eosinophils and obliterative vasculitis. It was concluded that the reaction had been triggered by an excessive release of metal in a patient with metal hypersensitivity.

Although corrosion of cobalt-based alloys has not been an issue of major clinical significance (Williams 1982; Wright, Burstein and Bartel 1985), it is well recognised that metallic implants do release ions to their surroundings. This has been demonstrated experimentally (Rae 1979; Smith and Black 1985) as well as in clinical studies (Coleman, Herrington and Scales 1973; Dobbs and Minski 1980; Michel et al 1984; Bartolozzi and Black 1985).

The significance of elevated levels of systemic metal is uncertain. Biological effects with metabolic, bacteriological, and immunogenic consequences have been pointed out (Merritt and Brown 1985; Black 1988). The possible carcinogenic effect of metallic implants has also become a matter of growing concern. Reports on local tumours have become more frequent (Apley 1989), and an increased incidence of lymphatic and haemopoietic malignancies associated with hip implants has been indicated by Gillespie et al (1988) and by Visuri and Koskenvuo (1989).

Corrosion. Cobalt-chromium alloys as well as stainless steels owe their corrosion resistance to a protective film of chromium oxides. Chemical or mechanical breakdown of this protective layer may cause localised corrosion 
such as pitting, crevicing, fretting, or stress corrosion. Several factors, including surface finish and geometry, local oxygen concentration and $\mathrm{pH}$, mechanical stresses and the presence of proteins may influence the tendency for corrosion (Kruger 1979; Williams 1982; Williams, Brown and Merritt 1988).

Most reports of in vivo corrosion of surgical implants refer to multicomponent stainless steel devices, describing, for example, crevice and fretting corrosion between screw heads and plate holes. Metallurgical analysis of retrieved implants has shown that the materials do not always meet current standards (Harris 1979; Weinstein et al 1979; Cook et al 1987). In vivo corrosion of cobaltbased alloys is very uncommon, but some cases of the corrosion of multi-part devices have been reported (Scales 1971; Cohen and Wulff 1972; Rose, Schiller and Radin 1972). Metallurgical flaws, such as inclusions and porosities in cast devices have been associated with corrosion (Williams 1982), and with the fatigue failure of implants (Galante 1980; Cook et al 1986). Excessive metal release from porous coatings and other surface modifications which produce an increased surface area has also become a matter of concern (Buchert et al 1986).

In the present study we have demonstrated macroscopic corrosion in four of nine prostheses of modular design, confined to the interface at the head-neck junction. Porosities and chemical inhomogeneity have been observed close to these interfaces. There were no marks or scratches indicating that motion had occurred at the junction. Furthermore all modular heads were firmly fixed to the neck taper, and could not be removed without tools. Therefore, fretting as a cause of corrosion seems unlikely. Despite the fact that the metallurgy of older one-piece prostheses was not always optimal, corrosion of these implants has been extremely rare. Consequently, metallurgical shortcomings alone can hardly be blamed.

Crevice corrosion, facilitated by structural imperfections, is probably a better explanation. Theoretically, a poor mechanical fitting at the junction could also contribute to corrosion by enlarging the volume of the crevice. Unfortunately the heads were cut before we considered this possibility. The properties of cast cobaltchromium implants have improved in later years as modern processing techniques, such as heat treatment or hot isostatic pressing, have improved their microstructure. The risk of corrosion may thus be small but should not be neglected. However small, unnecessary junctions should be avoided in order to minimise corrosion. This is a well-known principle in marine engineering; in our opinion we buy the benefits of modular design at the cost of an increased risk of metal ion release.

The authors wish to thank Connie Westman, Master of Engineering, at the Swedish Institute for Metals Research, Stockholm, for performing the metallographic investigations presented in this paper.

Although none of the authors have received or will receive benefits for personal or professional use from a commercial party related directly or indirectly to the subject of this article, benefits have been or will be received but are directed solely to a research fund, foundation, educational institution, or other non-profit institution with which one or more of the authors is associated.

\section{REFERENCES}

Apley AG. Editorial. Malignancy and joint replacement: the tip of an iceberg? J Bone Joint Surg [Br] 1989; 71-B:1.

Bartolozzi A, Black J. Chromium concentrations in serum, blood clot and urine from patients following total hip arthroplasty. Biomaterials $1985 ; 6: 2-8$.

Black J. Editorial: Does corrosion matter? J Bone Joint Surg [ Br] 1988; 70-B:517-20.

Buchert PK, Vaughn BK, Mallory TH, Engh CA, Bobyn JD. Excessive metal release due to loosening and fretting of sintered particles on porous-coated hip prostheses: report of two cases. J Bone Joint Surg [ Am] 1986; 68-A; 606-9.

Cohen $\mathbf{J}$, Wulf $\mathbf{J}$. Clinical failure caused by corrosion of a vitallium plate: case report, new testing methods for crevice corrosion, and new techniques for fashioning cobalt chromium alloys to be used in surgical implants. J Bone Joint Surg [ Am] 1972; 54-A :617-28.

Coleman RF, Herrington J, Scales JT. Concentration of wear products in hair, blood, and urine after total hip replacement. $\mathrm{Br}$ Med J $1973 ; 1527-9$.

Cook SD, Kester MA, Harding AF, Brown TD, Sandborn PM. Metallurgical analysis of five failed cast cobalt-chromium-molybdenum alloy hip prostheses. J Rehabil Res Dev 1986; 23:27-36.

Cook SD, Thomas KA, Harding AF, et al. The in vivo performance of 250 internal fixation devices: a follow-up study. Biomaterials 1987; 8:177-84.

Dobbs HS, Minski MJ. Metal ion release after total hip replacement. Biomaterials 1980; 1:1933-8.

Evans EJ, Thomas IT. The in vitro toxicity of cobalt-chromemolybdenum alloy and its constituent metals. Biomaterials 1986; 7:25-9.
Evans EM, Freeman MAR, Miller AJ, Vernon-Roberts B. Metal sensitivity as a cause of bone necrosis and loosening of the prosthesis in total joint replacement. J Bone Joint Surg [Br] 1974; $56-\mathrm{B}: 626-42$

Galante JO. Causes of fractures of the femoral component in total hip replacement. J Bone Joint Surg [Am] 1980; 62-A :670-3

Gillespie WI, Frampton CMA, Henderson RI, Ryan PM. The incidence of cancer following total hip replacement. J Bone Joint Surg [Br] 1988; 70-B:539-42.

Halpin DS. An unusual reaction in muscle in association with a vitallium plate: a report of possible metal hypersensitivity. $J$ Bone Joint Surg [Br] 1975; 57-B:451-3.

Harris B. Corrosion of stainless steel surgical implants. $J$ Med Engineering and Technology 1979; 3:117-22.

Howie DW, Vernon-Roberts B. The synovial response to intraarticular cobalt-chrome wear particles. Clin Orthop 1988; 232:244-54.

Jones DA, Lucas HK, O'Driscoll M, Price CHG, Wibberley B. Cobalt toxicity after McKee hip arthroplasty. J Bone Joint Surg [ Br] 1975; 57-B:289-96

Kruger J. Fundamental aspects of the corrosion of metallic implants. In: Syrett BC, Acharya A, eds. Corrosion and degradation of implant materials. Philadelphia: American Society for Testing and Materials, 1979:107-27.

Kumar P, Hickl AJ, Asphahani AI, Lawley A. Properties and characteristics of cast, wrought, and powder metallurgy processed cobalt-chromium molybdenum implant materials. In : Fraker AC, Griffin $\mathrm{CD}$, eds. Corrosion and degradation of implant materials. Philadelphia: American Society for Testing and Materials, 1985:30-56. 
Mathiesen EB, Lindgren JU, Reinholt FP, Sudmann E. Tissue reactions to wear products from polyacetal (Delrin) and UHMW polyethylene in total hip replacement. J Biomed Mater Res 1987; $21: 459-66$.

Merritt K, Brown SA. Biological effects of corrosion products from metals. In: Fraker AC, Griffin CD, eds. Corrosion and degradation of implant materials. Philadelphia: American Society for Testing and Materials, 1985:195-207.

Michel R, Hofmann J, Löer F, Zilkens J. Trace element burdening of human tissues due to the corrosion of hip-joint prostheses made of cobalt-chromium alloys. Arch Orth Trauma Surg 1984; 103:85-95.

Mital M, Cohen J. Toxicity of metal particles in tissue culture. Part II: a new assay method using cell counts in the lag phase. J Bone Joint Surg [ Am] 1968; 50-A :547-56.

Pappas AM, Cohen J. Toxicity of metal particles in tissue culture. Part $1:$ a new assay method using cell counts in the phase of replication. J Bone Joint Surg [Am] 1968; 50-A :535-47.

Pizzoferrato A, Savarino L, Stea S, Tarabusi C. Results of histological grading on 100 cases of hip prosthesis failure. Biomaterials 1988; 9:314-8.

Rae T. A study on the effects of particulate metals of orthopaedic interest on murine macrophages in vitro. J Bone Joint Surg [Br] 1975; 57-B:444-50.

Rae T. Comparative laboratory studies on the production of soluble and particulate metal by total joint prostheses. Arch Orthop Trauma Surg 1979; 95:71-9.

Rae T. The toxicity of metals used in orthopaedic prostheses: an experimental study using cultured human synovial fibroblasts. $J$ Bone Joint Surg [ Br] 1981; 63-B:435-40.

Rose RM, Schiller AL, Radin EL. Corrosion-accelerated mechanical failure of a vitallium nail plate. J Bone Joint Surg [Am] 1972; 54A :854-6.

Scales JT. Examination of implants removed from patients. $J$ Bone Joint Surg [Br] 1971; 53-B:344-6.
Smith GK, Black J. Estimation of in vivo Type 316L stainless steel corrosion rate from blood transport and organ accumulation data. In: Fraker AC, Griffin CD, eds. Corrosion and degradation of implant materials. Philadelphia: American Society for Testing and Materials, 1985:223-47.

Svensson O, Mathiesen EB, Reinholt FP, Blomgren G. Formation of a fulminant soft-tissue pseudotumor after uncemented hip arthroplasty: a case report. J Bone Joint Surg [ Am] 1988; 70-A :1238-42.

Syrett BC, Davis EE. Crevice corrosion of implant alloys - a comparison of in-vitro and in-vivo studies. In: Syrett BC, Acharya A, eds. Corrosion and degradation of implant materials. Philadelphia: American Society for Testing and Materials, 1979:229-44.

Vernon-Roberts D, Freeman MAR. The tissue response to total joint replacement prostheses. In: Swanson SAV, Freeman MAR, eds. The scientific basis of joint replacement. Tunbridge Wells: Pitman Medical, 1977:86-129.

Visuri T, Koskenvuo M. Cancer-risk after McKee-Farrar total hip replacement. Acta Orthop Scand 1989; 60(Suppl 231):25.

Weinstein AM, Spires WP Jr, Klawitter JJ, Clemow AJT, Edmunds JO. Orthopaedic implant retrieval and analysis study. In: Syrett BC, Acharya A, eds. Corrosion and degradation of implant materials. Philadelphia: American Society for Testing and Materials, 1979; 212-28.

Williams DF. Corrosion of orthopaedic implants. In: Williams DF, ed. Biocompatibility of orthopaedic implants. Vol 1. Boca Raton: CRC Press, 1982; 197-229.

Williams RL, Brown SA, Merritt K. Electrochemical studies on the influence of proteins on the corrosion of implant alloys. Biomaterials $1988 ; 9: 181-5$.

Wright TM, Burstein AH, Bartel DL. Retrieval analysis of total joint replacement components: a six-year experience. In: Fraker AC, Griffin CD, eds. Corrosion and degradation of implant materials. Philadelphia: American Society for Testing and Materials, 1985:415-28. 